\title{
The Effect of Accounting Firms Size on Audit Fees
}

\author{
Liangcheng Wang \\ Business School \\ Sichuan University \\ Chengdu, China
}

\author{
Yanzhi Zhou \\ Business School \\ Sichuan University \\ Chengdu, China
}

\begin{abstract}
The study of audit fees is one of the most important issues in auditing market. Audit fees are the "economic bridge" between listed companies and accounting firms. Reasonable audit fees can improve the audit quality. This paper examines the effect of accounting firms on audit fees, and discusses whether there are significant differences in audit fees among different size of accounting firms. Through studying the audit fees of A-share listed companies of China from 2013 to 2015, we find that compared with the local accounting firms, the big four accounting firms have obtained a significant audit fees premium. And compared with the small and medium local accounting firms, the large local accounting firms have also obtained a significant audit fees premium.
\end{abstract}

Keywords-accounting firms; size; audit fees

\section{INTRODUCTION}

On December 24th, 2001, China Securities Regulatory Commission promulgated the "No.6 Q\&A of Information Disclosure by Companies that Offer Securities to the PublicPaying the Remuneration of Accounting Firms and its Disclosures", which explicitly requires listed companies to pay the remuneration of the accounting firms as an important matter to be disclosed, the promulgation of the norm provides an opportunity for the related research of Chinese scholars on audit fees. Since 2006, the Chinese Institute of Certified Public Accountants has released the top 100 annual comprehensive information of annual accounting firms annually, providing authoritative reference information for the public to understand the comprehensive ability of accounting firms. In order to promote the Certified Public Accountant Industry bigger and stronger, the government departments have issued the "Several Opinions on Accelerating the Development of CPA Industry in China" and the "Guidelines on the Merger Procedure of Certified Public Accountants", and actively promote the merger among accounting firms to expand the scale and raise the level. The merger tide of accounting firms in our country has been on the rise. Accounting firms want to expand their scale. The accounting firms with annual revenues of over 100 million are increasing every year, and there were 63 accounting firms which annual income over 100 million in 2016. Audit fees are an important condition for the existence and development of accounting firms. Will large accounting firms charge higher audit fees? This article will use the date of Ashare listed companies from 2013 to 2015 to answer the question.

This paper researches 7023 A-share listed companies from 2013 to 2015 , examining the effect of accounting firms size on audit fees, and we find that the size of accounting firms will affect the audit fees, there is an audit fees premium among large accounting firms. Compared with the local accounting firms, the big four accounting firms have obtained a significant audit fees premium. And compared with the small and medium local accounting firms, the large local accounting firms have also obtained a significant audit fees premium.

This paper expands the research about audit fees in our country. It provides the support for the accounting firm to expand their scale, and provides evidence for the debate about whether there is audit fees premium among accounting firms in China. According to the large sample data, there is a significant audit fees premium among large accounting firms.

The remainder of the paper proceeds as follows. The next section develops the hypotheses. Section 3 describes the research design. Section 4 presents empirical results. Section 5 concludes the paper.

\section{HYPOTHESES DEVELOPMENT}

This section reviews the relevant research, and analyzes the relationship between accounting firms size and audit fees. Then it puts forward research hypotheses.

Whether the size of the accounting firms will generate an audit fees premium is highly controversial at home and abroad. Simunic (1980) took the American audit market as the research object, and the result showed that the American audit market is a fully competitive market. There was no audit fees premium in the big eight accounting firms. The correlation between the scale of the accounting firms and audit fees was not significant. Francis (1984) argued that because of the high monopoly of the Big eight accounting firms in the US market and the generally large size of US public companies, she found that there was no audit fees premium in the big eight accounting firms in the United States. She studied Australian listed companies, and found that the big eight accounting firms had a significant audit fees premium. Firth (1985) found that accounting firms size had no significant effect on audit fees. Johnson and Walker (1995) further examined the audit market in New Zealand based on Firth's research. The result showed that the size of the accounting firms significantly affected the audit fees and that the audit fees of the five largest accounting firms were about an average of 24 percentage points higher than those of other firms. Gul (1999) researched the Hong Kong listed companies, also found that large accounting firms had obtained a significant audit fees premium compared to small accounting firms. Choi et al. (2008) explored the relationship between 
accounting firms size and audit fees from the perspective of the legal environment. The study found that when the implementation of the national legal system increased, the big four accounting firms would charge more audit fees than other accounting firm, and in countries where the legal system was weak, the audit fees premium of the big four accounting firms was even more obvious.

It is unclear whether the accounting firms size will produce an audit fees premium in our country. Wu (2003) studied and analyzed the impact of corporate earnings management on audit fees, and found there was a significant positive correlation between the big four accounting firms and the annual audit fees of listed companies. Zhang and Wang (2007) took the A-share listed companies of 2005 as research subjects, and found there were significant influences on the audit fees if audited by the big four accounting firms and the top-10 domestic accounting firms. According to the analysis of the IPO audit market, Wang (2010) found that the big four accounting firms had made a significant audit fees premium. Wang and Chen (2010) found that the audit fees of large accounting firms were more expensive than small accounting firms. However, Liu et al. (2003), Wang et al. (2005) and Zhang et al. (2005) found that there was no significant audit fees premium on the size of accounting firms.

Francis (1984) argued that the auditing services provided by the large accounting firms are of high quality. If the market is full of competition and short of scale economies, large accounting firms will charge higher audit fees than small ones. Dye (1993) considered that the value of the audit coming from the accounting firm's information value and deep pocket insurance value. The size of the accounting firm often has a brand effect in the audit market. The size of the firm represents the service quality, independence and reputation, and the large accounting firms have a more obvious deep pocket effect. The large accounting firms will face huge loss of property and reputation once prosecuted because of audit failure, so they will give full consideration to audit risk factors. As a result, the large accounting firms charge higher audit fees. The Chinese government continuously promotes the merger between accounting firms to promote the expansion of scale and the improvement of level. At the same time, there has not yet formed the scale economies of the accounting firms because of the over competition in the audit market. In China, the big four accounting firms continue to dominate the audit market, and a lot of large local accounting firms are also accumulate, ranking only behind the big four in the rankings released by China Association of Certified Public Accountants. Therefore, this paper divides the large accounting firms into two levels: the big four accounting firms and the top ten local accounting firms of China. Based on the previous theoretical analysis, the following hypotheses are proposed.

Hypothesis 1. Compared with the local accounting firms, the big four accounting firms obtain a significant audit fees premium.

Hypothesis 2. Compared with the small and medium local accounting firms, the large local accounting firms obtain a significant audit fees premium.

\section{RESEARCH DESIGN}

This paper takes the A-share listed companies of China from 2013 to 2015 as the research object, and the sample data comes from the CSMAR database. After removing some of the samples, the final sample is 7023 companies. The paper research the effect of accounting firms size on audit fees through SPSS software for data analysis.

There are many ways to measure the size of an accounting firm, such as the total income of an accounting firm, the auditing income of an accounting firm, the assets of the audited entity, and the total income of the audited entity. The ranking of top 100 accounting firms published by the China Association of Certified Public Accountants is calculated in accordance with various indicators such as the total income of the accounting firm. Income is the basis for the survival and development of accounting firms. This paper selects the total income of accounting firms as a measure of their size. According to the total income index data announced by China Association of Certified Public Accountants, the accounting firms are divided into three categories: the big four, the large local and the small and medium local. The big four accounting firms include: PricewaterhouseCoopers, Deloitte Touche Tohmatsu, Ernst \& Young, and KPMG. The large local accounting firms refer to the top 15 accounting firms in three national rankings from 2013 to 2015 (excluding the big four). They include the following 10 accounting firms: Ruihua Accounting Firm, Lixin Accounting Firm, Tianjian Accounting Firm, Dahua Accounting Firm, Xinyong Zhonghe Accounting Firm, Tianzhi Guoji Accounting Firm, Zhitong Accounting Firm, Daxin Accounting Firm, Zhonghui Accounting Firm, Zhongshen Zhonghuan Accounting Firm.

The factors that influence the audit fees mainly include the factors that affect the audit costs and the factors that affect the audit risk. Learning from the previous research, we take the two types of factors as the controlling factors. In order to test the hypothesis 1 and hypothesis 2 , we construct the model (1) and model (2).

Fee $=$ b0 + b1Big $4+$ b2Size + b3Recv + b4Inv + b5Lev + b6Roa + b7Loss + b8Opinion + b9Year2015 + b10Year2014 + $\varepsilon$

Fee $=$ b0 + b1Big4 + b2Local10 + b3Size + b4Recv + b5Inv + b6Lev + b7Roa + b8Loss + b9Opinion + b10Year2015 + b11Year2014 $+\varepsilon$

The model (1) is used to test whether the big four get higher audit fees than the local accounting firms. Based on the hypothesis 1, Big4 have a significant positive correlation with the Fee, the regression coefficient b1 of Big4 in the model (1) should be significantly positive. The model (2) is used to test whether large local accounting firms are able to obtain higher audit fees than local small and medium local accounting firms. According to hypothesis 2, Local10 and Fee have a significant positive correlation. The regression coefficient b2 of Local10 in the model (2) should be significantly positive.

Fee is the dependent variable and it refers to the natural logarithm of audit fees. Big4 and Local10 are independent variables, and they are dummy variables. Big4 and Local10 are used to measure the size of accounting firms. Big4 indicates 
whether the listed company audited by the big four accounting firms. Big4 equals 1 if the listed company audited by the big four accounting firms, and 0 otherwise. Local10 indicates whether the listed company audited by the large local accounting firms. Local10 equals 1 if the listed company audited by the large local accounting firms, and 0 otherwise.

We also include other control variables. Size refers to the natural logarithm of the total assets of the listed company at the end of the year. Recv refers to the ratio of accounts receivable to total assets. Inv refers to the ratio of inventory to total assets. Lev refers to the asset-liability ratio. Roa refers to the return on assets. Loss, Opinion, Year2015 and Year2014 are dummy variables. Loss equals 1 if the listed company makes a loss, and 0 otherwise. Opinion equals 1 if the audit opinion is a nonstandard audit opinion, and 0 otherwise. Year2015 equals 1 if the year is 2015, and 0 otherwise. Year2014 equals 1 if the year is 2014 , and 0 otherwise.

Generally speaking, there are mainly two kinds of factors that affect audit fees, one of which affects the audit costs, such as the size of the audited entity and the complexity of the auditing business. The other type affects the audit risk, such as the capital structure and the profitability of the audited entity. Learning from the research of predecessors, we need to control the influence of these two types of factors. Among the control variables, Size is used to measure the size of the audited entity, Recv and Inv are used to measure the complexity of the auditing business, and they are used to control the impact of the audit cost on the audit fees. Lev, Roa, Loss, Opinion are used to measure the risk and performance status of the audited entity, and to control the impact of audit risk on audit fees.

\section{EMPIRICAL RESULTS}

\section{A. Descriptive Statistics}

"Table I" shows the descriptive statistics of the data of 7023 A-share listed companies from 2013 to 2015.

As can be seen from table 1, the mean of natural logarithm of the audit fees is 13.51. Going back to the original data, the average of audit fees is 930,000 yuan, the maximum is 35.7 million yuan and the minimum is 75,000 yuan. There are $4 \%$ of the listed companies hiring the big four accounting firms, and $68 \%$ of the listed companies hire the top ten local accounting firms, indicating that most of listed companies have a strong desire to hire large accounting firms. The mean of the assetliability ratio is $45.35 \%$, the ratio of loss companies is $12 \%$, indicating that the financial risk of listed companies is moderate. There are $4 \%$ of the accounting firms issuing nonstandard audit opinion, and $96 \%$ of the annual report of listed companies were issued standard unqualified audit opinion, indicating that most accounting firms accept the financial information disclosed by the listed company in the financial statements.

\section{B. Correlation Analysis}

The correlation analysis of dependent variable and other variables is shown at "Table I". It indicates that the audit fees are significantly related to the big four accounting firms and the top ten local accounting firms at the $1 \%$ significance level.

TABLE I. DESCRIPTIVE STATISTICS OF VARIABLES

\begin{tabular}{|l|c|c|c|c|c|c|}
\hline \multicolumn{1}{|c|}{ Variables } & N & Mean & Median & Max. & Min. & Std.Dev. \\
\hline Fee & 7023 & 13.51 & 13.46 & 17.39 & 11.23 & 0.59 \\
\hline Big4 & 7023 & 0.04 & 0 & 1 & 0 & 0.19 \\
\hline Local10 & 7023 & 0.68 & 1 & 1 & 0 & 0.47 \\
\hline Size & 7023 & 21.99 & 21.86 & 27.70 & 14.94 & 1.25 \\
\hline Recv & 7023 & $11.59 \%$ & $8.99 \%$ & $75.97 \%$ & 0 & $10.87 \%$ \\
\hline Inv & 7023 & $15.77 \%$ & $11.67 \%$ & $93.97 \%$ & 0 & $15.57 \%$ \\
\hline Lev & 7023 & $45.35 \%$ & $42.93 \%$ & 63.97 & $-19.47 \%$ & $79.80 \%$ \\
\hline Roa & 7023 & $3.75 \%$ & $3.25 \%$ & 10.03 & -14.59 & $25.55 \%$ \\
\hline Loss & 7023 & 0.12 & 0 & 1 & 0 & 0.32 \\
\hline Opinion & 7023 & 0.04 & 0 & 1 & 0 & 0.20 \\
\hline Year2015 & 7023 & 0.33 & 0 & 1 & 0 & 0.47 \\
\hline Year2014 & 7023 & 0.33 & 0 & 1 & 0 & 0.47 \\
\hline
\end{tabular}

$\mathrm{N}$ refers to the number of the samples. Max. refers to the maximum. Min. refers to the minimum. Std.Dev. refers to the standard deviation

Size, Recv, Inv, Lev, Loss are significantly related to the audit fees at the $1 \%$ significance level. Opinion is significantly related to the audit fees at the $5 \%$ significance level, but there is no significant correlation between Roa and audit fees. Most of the variables are significantly related to audit fees, which prove the effectiveness of the model. Though observing the correlation and significant degree among variables, the correlation coefficient among the great majority of variables is small, and there is no serious multicollinearity between the variables.

\section{Multiple Regression Analysis}

"Table II" and "Table III" show the results of multiple regression analysis of model (1) and model (2). On the whole, the explanatory power of model (1) and model (2) are both strong, the goodness of fit and the adjusted goodness of fit are all greater than 0.53 , and the equation is significant at $1 \%$ level.

In the regression results, the regression coefficient of Big4 in model (1) is significantly and positively correlated at the level of 0.01 , indicating that the audit fees of the big four accounting firms are significantly higher than the audit fees of local accounting firms, which is consistent with the hypothesis 1 in this paper. Big4 and Locallo are significant at $1 \%$ level, 
and the coefficients are positive in model (2), indicating that the big four accounting firms and the top ten local accounting firms charge more than other accounting firm, which support hypothesis 2 .

Among the control variables, Size is significantly and positively related to Fee, indicating that the size of the audited entity is an important factor affecting the audit fees. There is a significant positive correlation between Recv and Fee, indicating that the complexity of the economic operations of listed companies will also affect the audit fees. Opinion is also significantly and positively related to Fee, indicating that the issuance of non-standard audit opinions will increase the audit workload for accounting firms, thus increasing audit fees.

TABLE II. CORRELATION ANALYSIS OF VARIABLES

\begin{tabular}{|c|c|c|c|c|c|c|c|c|c|c|c|c|}
\hline \multirow{2}{*}{$\begin{array}{c}\text { Dependent } \\
\text { Variable }\end{array}$} & \multirow{2}{*}{ Index } & \multicolumn{2}{|c|}{ Independent Variables } & \multicolumn{9}{|c|}{ Control Variables } \\
\hline & & Big4 & Local10 & Size & Recv & Inv & Lev & Roa & Loss & Opinion & Year2015 & Year2014 \\
\hline \multirow{3}{*}{ Fee } & Coeff. & $0.363 * *$ & $-0.031 * *$ & $0.700 * *$ & $-0.075 * *$ & $0.083 * *$ & $0.089 * *$ & -0.008 & $-0.034 * *$ & $-0.029 *$ & $0.101 * *$ & -0.009 \\
\hline & Sig. & 0.000 & 0.009 & 0.000 & 0.000 & 0.000 & 0.000 & 0.483 & 0.005 & 0.017 & 0.000 & 0.430 \\
\hline & $\mathrm{N}$ & 7023 & 7023 & 7023 & 7023 & 7023 & 7023 & 7023 & 7023 & 7023 & 7023 & 7023 \\
\hline
\end{tabular}

a. Coeff. refers to the correlation coefficient. Sig. refers to the significance. $\mathrm{N}$ refers to the number of the samples. *, ** represents significance at the $5 \%, 1 \%$ level (two-tailed test).

TABLE III. MULTIPLE REGRESSION ANALYSIS

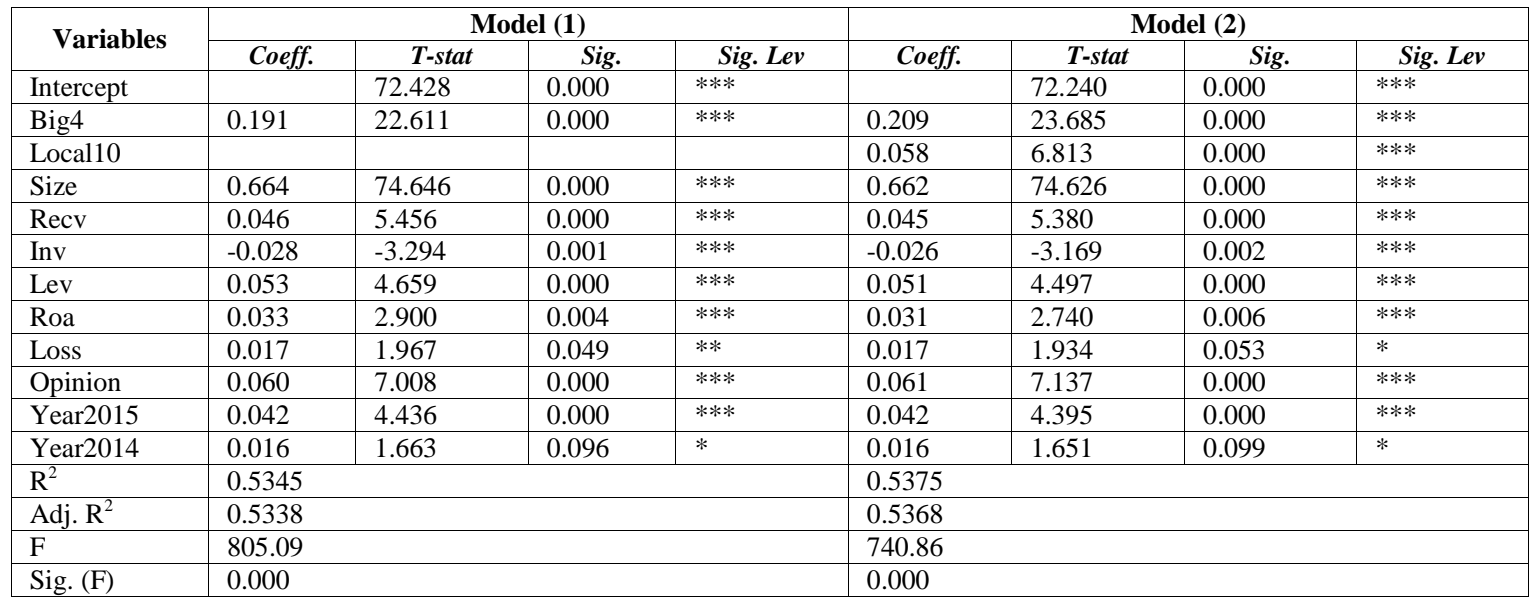

b. Coeff. refers to the correlation. T-stat refers to the T-Statistics. Sig. refers to the significance. Sig. Lev N refers to the significance level. $\mathrm{R}^{2}$ refers to the deterministic coefficient of the equation. Adj. R2 refers to the $\mathrm{R}^{2}$ after adjustment. F refers to the F-Statistics. Sig. (F) refers to the significance of the regression equation. *,**, *** represents significance at the $10 \%, 5 \%, 1 \%$ level (two-tailed test)

\section{CONCLUSION}

This paper examines the effect of accounting firms size on audit fees in China. The empirical data shows that the larger the accounting firm, the higher audit fees. Compared with the local accounting firms, the big four accounting firms have obtained a significant audit fees premium. And compared with the small and medium local accounting firms, the large local accounting firms have also obtained a significant audit fees premium. The size of the accounting firm will affect the audit fees. The large accounting firms have an audit fees premium, which generally charge more than the small accounting firms. This is because there is excessive competition in the audit market in our country and the situation of scale economy of accounting firms has not been formed yet. In the meantime, the government promotes the merger of accounting firms in our country to promote the rapid expansion of accounting firms. The large accounting firms can provide differentiated audit services, and they have information value in terms of resource allocation. The large accounting firms have obvious deep pocket insured value, resulting in large audit fees will charge a higher audit fees. The research of the paper supports the way that accounting firms compete to expand their scale, which shows the importance and necessity of the accounting firm becoming bigger and stronger. At the same time, the result provides new evidence for the research on the relationship between accounting firms size and audit fees.

\section{REFERENCES}

[1] Simunic,Dan A.. The Pricing of Audit Services:Theory and Evidence[J]. Journal of Accounting Research, 1980,18(1):161-190

[2] Francis,Jere R.. The Effect of Audit Firm Size on Audit Prices:A Study of the Australian Market[J]. Journal of Accounting and Economics, 1984,6(2):133-151

[3] Firth,Michael. An Analysis of Audit Fees and Their Determinants in New Zealand $[\mathrm{J}]$. Auditing: A Journal of Practice and Theory, 1985,4(2):23-37

[4] Johnson,Ericn N. \& Walker, Kenton B.. Supplier Concentration and Pricing of Audit Services in New Zealand[J]. Auditing:A Journal of Practice and Theroy, 1995,14(2):74-89

[5] Gul,Ferdinand A.. Audit Prices,Product Differentiation and Economic Equilibrium[J]. Auditing:A Journal of Practice and Theory, 1999,18(1):90-100

[6] Choi,Jong-Hag \& Kim,Jeong-Bon \& Liu,Xiaohong \& Simunic, Dan A.. Audit Pricing, Legal Liability Regimes and Big4 Premiums:Theory and Cross-country Evidence[J]. Contemporary Accounting Research, 2008,25(1):55-99

[7] Wu Lina. Analysis of the Impact of Earnings Management on Audit Fees: Evidence from the First Audit Fee Disclosure by Chinese Listed Companies[J]. Accounting Research, 2003(12):39-44 
[8] Zhu Xiaoping \& Guo Zhiying. Research on the Information Content of Increasing Auditing Cost without Replacing Certified Public Accountants: A Clues Analysis of Purchasing Auditing Opinion without Replacing Certified Public Accountants[J]. Auditing Research, 2006(2):64-68

[9] Han Hongling \& Chen Hanwen. Is the Professionalization of Accounting Firms An Effective Competitive Strategy? Evidence from the Chinese Audit Market [J]. Auditing Research, 2008(1):53-60

[10] Liu Yuting. A New Milestone in the Process of China's Certified Public Accountants Industry Reform and Development: Interpretation of "Several Opinions on Accelerating the Development of China's CPA Industry"[J]. Journal of Accounting Research, 2009(10):3-9

[11] Wang Liangcheng \& Chen Hanwen. Legal Environment, Firm Size and Audit Pricing[J]. Finance and Trade Economics, 2010(4):69-75

[12] Zhou Zhongsheng. Accounting Firm Mergers and Audit Fees[J]. Finance Theory and Practice, 2013(6):65-70 